кандидат педагогічних наук, доцент

(Житомирський державний університет імені Івана Франка) avd23v@ukr.net

ORCID : $0000-0002-6496-0145$

\title{
ТЕОРЕТИЧНІ ОСНОВИ РЕАЛІЗАЦІЇ ПРИНЦИПУ НАСТУПНОСТІ ПРИ ВИКЛАДАННІ ПРИРОДНИЧИХ ДИСЦИПЛІН У ЗАГАЛЬНООСВІТНІЙ ШКОЛІ
}

У статті розкрито важливість забезпечення принщипу наступності природничої освіти між дошкільною, початковою та основною школою, який надалі поглиблюється на засадах профільного навчання в старшій школі. 3'ясовано, щуо забезпечення наступності природничої освіти здійснюється иілеспрямовано та багатоаспектно, иляхом формування природничо-наукової компетентності та предметних компетентностей як обов 'язкових складових загальної культури учнів.

Ключові слова: перспективність, принцип наступності, предметна компетентність, природничонаукова компетентність.

Вступ. В умовах євроінтеграційних процесів, які відбуваються сьогодні в Україні важливою проблемою стає проблема реформування загальної середньої освіти на засадах Концепції Нової української школи. Вагомим внеском у навчанні учнів $є$ розробка змісту й методики навчання 3 урахуванням нових Державних стандартів, оновлених навчальних програм для учнів загальноосвітньої школи. Успішному розв'язанню цієї проблеми сприяє створення розвивального середовища на засадах неперервності, узгодженості організації навчально-виховного процесу в загальноосвітній школі.

Встановлено, що основне завдання підготовки професіонала нового типу, що поєднує в собі моральність і культуру, освіченість, вміння рефлексивно оцінювати свою діяльність і перебудовувати стратегію в змінюваних ситуаціях, стає безумовним пріоритетом сьогодення.

Динаміка шкільних перетворень лише загострює проблему відповідності. Державні вимоги до загальноосвітньої підготовки учнів загальноосвітньої школи вбачають удосконалення професійної підготовки майбутніх учителів. Система підготовки вчителів повинна враховувати те, що змінюється ідеологія шкільної освіти, на перше місце стає розвиток особистості та ії творчого потенціалу [1].

Аналіз останніх досліджень і публікацій. Проблема наступності у викладанні природничих дисциплін є предметом розгляду в працях учених, зокрема: у дидактиці (А. Алексюк, С. Архангельський, С. Гончаренко, Ю. Бабанський та ін.), у психології (Л. Виготський, О. Леонтьєв, С. Рубінштейн, Н. Тализіна та ін.), у педагогіці професійної освіти (С. Батишев, В. Безрукова, А. Бєляєва, Р. Гуревич, О. Коваленко, І. Козловська, Н. Ничкало, В. Сластьонін та ін.), у неперервній професійній освіті (А. Литвин, П. Олійник та ін.), у проблемі наступності навчання дошкільника та молодшого школяра (О. Більська, А. Богуш, Л. Калмикова, І. Козак, Л. Коломієць, О. Кононко, О. Проскура, Т. Степанова, Т. Фадєєва та ін.), у змісті природничої освіти між дітьми старшого дошкільного та молодшого шкільного віку (Т. Байбара, Н. Буринська, Н. Коваль, 3. Плохій та ін.).

Разом з тим, упродовж останніх років спостерігається неузгодженість теоретичної розробки проблеми забезпечення наступності природничої освіти між дошкільною - початковою - загальною середньою освітою та їх практичним впровадженням.

Принцип наступності природничої освіти передбачає встановлення тісних зв'язків між ланками в системі неперервної освіти, а саме "узгодженість" у цілях, змісті, організаційно-методичному забезпеченні етапів освіти, які межують один з одним.

Метою статті $\epsilon$ теоретичне обгрунтування реалізації принципу наступності при викладанні природничих дисциплін у загальноосвітній школі.

Методи дослідження: аналіз психолого-педагогічної, науково-методичної літератури, систематизація, синтез, узагальнення, що уможливили розкриття сутності проблеми.

Виклад основного матеріалу. Наступність у навчанні розглядається як безперервний процес розгортання структурних компонентів змісту, поступовий перехід від одного етапу навчання до іншого, поступове ускладнення навчальної інформації, послідовна зміна рівня вимог до обсягу і глибини засвоєння знань.

У шкільній практиці наступність передбачає психологічно і методично обгрунтовану побудову програм, підручників, з дотриманням послідовного ускладнення навчального матеріалу від простого до складного, організації самостійної роботи учнів.

Таким чином, кожен новий етап навчання повинен бути пов'язаний із попереднім, бути передумовою для подальшого навчання. Зв'язок і наступність етапів навчання сприяє доступності навчального матеріалу, міцності його засвоєння, поступовому ускладненні та розвитку пізнавальних здібностей учнів, що забезпечує системність у формуванні знань. 
Наступність і перспективність у формуванні змісту природничої освіти у загальноосвітніх навчальних закладах забезпечується орієнтацією на зміст та структуру освітньої галузі "Природознавство", Державних стандартів початкової та базової і повної середньої освіти.

Основними завданнями освітньої галузі "Природознавство" $\epsilon$ : оволодіння учнями понятійнотермінологічним апаратом природничих наук, засвоєння предметних знань та усвідомлення суті основних законів і закономірностей, що дають змогу зрозуміти перебіг природних явищ і процесів; усвідомлення ними фундаментальних ідей природничих наук; набуття досвіду практичної та експериментальної діяльності, здатності застосовувати знання в пізнанні світу, життєвій практиці; формування ціннісних орієнтацій на збереження природи, гармонійну взаємодію людини та природи.

Діючі навчальні програми створені на основі компетентнісного підходу. Компетентнісна освіта зорієнтована на практичний результат, досвід особистої діяльності, вироблення принципів, які призводять до істотних змін в організації навчання. Вона направлена на формування цінностей і життєво необхідних знань та умінь учнів. Реалізація компетентнісного підходу передбачає прогнозування результативної складової змісту, який вимагає певних змін у системі оцінювання навчальних досягнень учнів. Це свідчить про те, що результати навчальної діяльності повинні враховувати не тільки знання, уміння і навички. Метою навчання повинні стати сформовані компетентності як загальна здатність, що спирається на знання, досвід та цінності особистості. Компетентності не суперечать знанням, умінням і навичкам, а передбачають здатність їх осмисленого використання. Таким чином, удосконалення навчального процесу з використанням компетентнісного підходу полягає в тому, щоб навчити учнів застосовувати набуті знання й уміння в певних життєвих ситуаціях [1].

При вивченні природничих наук в учнів формується природничо-наукова компетентність та предметні компетентності як обов'язкові складові загальної культури учнів й розвитку їх творчого потенціалу. Природничо-наукова компетентність передбачає готовність учнів до пояснення та відповідного ставлення до природи, усвідомлення образу природи як сучасної природничо-наукової картини світу. Формування предметних компетентностей сприяє засвоєнню фундаментальних ідей, принципів, які сприяють виробленню навичок взаємодії з навколишнім середовищем.

Зміст природничої складової грунтується на принципі наступності між ланками освіти. Навчання учнів природознавства у початкових класах продовжується за тими ж змістовими лініями, що і у дошкільному закладі освіти. Однак, це не означає, що відбувається дублювання змісту, він поступово розширюється й поглиблюється. Учні продовжують формувати емпіричні знання, засвоювати теоретичні знання застосовувати їх у своїй практичній діяльності.

Вивчення матеріалу відбувається за спірально-концентричним принципом, що передбачає поглиблення й розширення знань та повторне вивчення певних тем з метою більш глибшого вивчення природних явищ та процесів, що відповідає віковим особливостям учнів.

Навчальний курс "Природознавства" початкової школи включає систему знань, уявлень про закономірності в природі та місце людини в ній; елементарні уявлення й поняття про об'єкти та явища природи, їх взаємозв'язки в системі "жива - нежива природа", "природа - людина", усвідомлення свого місця в навколишньому світі; дослідницьких умінь і здатності учнів спостерігати за об'єктами та явищами живої та неживої природи; досвіду навчально-пізнавальної та практичної природоохоронної діяльності учнів; способів навчально-пізнавальної діяльності учнів; мисленнєвих дій та операцій шляхом аналізу, порівняння, узагальнення й класифікації природних об'єктів, вироблення вміння розкривати причинно-наслідкові зв'язки в природі; навичок самостійної роботи учнів з інформацією; засвоєння норм морального, етичного та естетичного ставлення людини до природи [2].

Відповідно до змісту початкової загальної освіти, затвердженої Державними стандартами, у програмі "Природознавства" визначено такі змістові лінії: "Об’єкти природи"; "Взаємозв’язки в природі"; "Земля планета Сонячної системи"; "Україна на планеті земля"; "Рідний край"; "Охорона і збереження природи"; "Методи пізнання природи" [3].

Накопичення уявлень молодших школярів про об'єкти та явища природи здійснюється завдяки використанню місцевого природознавчого і краєзнавчого матеріалу, проведення систематичних екскурсій у природу, музей чи планетарій і т.д.

Використовуючи різні прийоми, засоби та методи навчання, вважаємо, що необхідно надавати перевагу практичним методам, зокрема: спостереженням у природі, власним дослідженням учнів, практичним роботам із демонстраційними та фронтальними дослідами, виготовленню моделей явищ природи та вмінню користуватися ними, екологічному моделюванню та прогнозуванню, вирішенню ситуативних завдань, роботі з інформаційними джерелами, а також практичній діяльності 3 охорони природи.

Кожний розділ програми передбачає проведення дослідницького практикуму, який сприяє виробленню самостійних дослідницьких умінь школярів у процесі розв'язання завдань практичного спрямування. 
Значну увагу необхідно надавати використанню сучасних освітніх технологій у навчальнопізнавальному процесі, зокрема: розвитку критичного мислення та креативності, проблемному підході до навчання, проектним технологіям. Проектна технологія потребує значної уваги педагогів, упровадження якої спрямовано на стимулювання інтересу учнів до нових знань, розвиток дитини через розв'язання проблем і застосування здобутих знань у конкретній діяльності. Запропоновані проекти мають бути короткотермінові та інтегровані за змістом [4].

В основній школі вивчення природничої складової відводиться пропедевтичному курсу "Природознавства", який будується на засадах наступності з початковою школою.

Аналіз навчальних програм з природознавства 4 класу початкової школи та 5 класу середньої школи дає можливість прослідкувати поступове поглиблення кожного розділу програми, зокрема вводяться дослідницькі практикуми, практичні роботи, розширюється проектна діяльність, спостереження, екскурсії. Програма природознавства 5 класу побудована на знаннях, уміннях і навичках, які діти отримали в початковій школі й поступово ускладнюється. Під час проведення уроків у 5 класі вчителі використовують різні форми їх проведення, що впливає на емоційну сферу учнів, покращенню уяви, мислення та свідчить про наступність, перспективність природничої освіти між початковою та основною ланками школи.

Вивчаючи "Природознавство", учні 5-х класів узагальнюють та поглиблюють природничі знання, уміння і навички, які набули у початковій школі, що є основою для подальшого вивчення предметів освітньої галузі "Природознавство" (біології, географії, фізики, хімії, астрономії). Поступово продовжується формування природознавчої компетентності учнів шляхом засвоєння системи інтегрованих знань про природу, та людину, системи екологічних знань. Учні опановують навчальнопізнавальну, природоохоронну діяльність у них розвиваються ціннісні орієнтації у ставленні до природи, до людей, до своєї країни [5].

Основна школа створює базову загальну середню освіту і разом з початковою школою складає основу загальноосвітньої підготовки, формує в учнів готовність до вибору й реалізації шляхів подальшого здобуття освіти. У старшій школі навчання, як правило профільне. Традиційними для вивчення $\epsilon$ навчальні предмети: фізика, хімія, біологія, географія тощо. Крім того, в їхньому змісті відображаються астрономічні знання, відомості про природокористування та екологічну безпеку, розкриваються наукові основи сучасних технологій і техніки тощо.

На основі аналізу освітньої програми, виокремлено наскрізні змістові лінії, спільні для освітньої галузі загалом: рівні та форми організації живої і неживої природи, що структурно подані в кожному компоненті освітньої галузі особливими для неї об'єктами й моделями; закони та закономірності природи; методи наукового пізнання, які специфічні для кожної з природничих наук; вплив природничонаукових знань на життя людини та їх роль у суспільному розвитку. Перераховані лінії наповнюються конкретним змістом під час вивчення кожної складової даної галузі. Зокрема, зміст біологічної складової спрямований на забезпечення засвоєння учнями знань про закономірності функціонування живих систем, їх розвиток та взаємодію, взаємозв'язок із неживою природою і формування уявлень про природничонаукову картину живого світу, синтез ідей про живі системи, оволодіння елементами наукового пізнання живої природи, формування наукового мислення, усвідомлення біосферної етики, розуміння необхідності раціонального використання й відновлення природних ресурсів, вироблення навичок застосування знань із біології у повсякденному житті.

Змістові лінії освітньої галузі "Природознавство" в шкільному курсі біології конкретизуються такими: молекулярно-клітинний рівень, організмів рівень, надорганізмовий рівень, система та еволюція організмів, методи наукового пізнання.

Висновки. Підсумовуючи вище зазначене, слід відзначити те, що наступність в навчальному процесі має велике значення. Вона дає можливість поступово збільшувати об'єм понять і способів дій, а також утворювати в учнів цілісне уявлення про наукове знання даної галузі науки, впливає на мотивацію, дозволяє вчителю застосовувати в навчальному процесі продуктивні способи навчання, дослідницькі й пошукові ситуації. Тим самим активізувати пізнавальну діяльність учнів, поступово збільшувати навантаження на школярів. Наступність, зазвичай, з'ясовується при зіставленні й логічному аналізі змісту, форм, методів і засобів викладання навчальних предметів даної освітньої галузі на різних ступенях навчання.

Зміст біологічної компоненти освітньої галузі "Природознавство" грунтується на принципі наступності між початковою та основною, основною і старшою школою, між загальною середньою та вищою освітою. Зокрема, він ураховує природознавчу підготовку учнів початкової школи за змістовими лініями освітньої галузі "Природознавство". Зміст біологічної освіти в старшій школі грунтується на базовій загальноосвітній підготовці учнів основної школи 3 вивченням живої природи. Цим забезпечується наступність у початковій, основній і старшій школах. 
Крім того існує об’єктивна необхідність у подальшому дослідженні проблеми підготовки майбутнього педагога до реалізації принципу наступності у викладанні природничих дисциплін у загальноосвітній школі.

\section{СПИСОК ВИКОРИСТАНИХ ДЖЕРЕЛ ТА ЛІТЕРАТУРИ}

1. Танська В. В. Методика навчання природознавства у початковій школі : [навч.-метод посібник] / В. В. Танська. - Житомир : Вид-во ЖДУ ім. І. Франка, 2014. - 236 с.

2. Романенко Л. Наступність природничої освіти в дошкіллі - початковій школі - основній школі / Л. Романенко // Особливості освіти дітей шестирічного віку: проблеми, пошуки, досвід, знахідки. Матеріали Всеукраїнської науково-практичної конференції (Київ, 19-20 листопада 2003 року). - К. : КМПУ імені Б. Д. Грінченка, 2004. - 138 с.

3. Державний стандарт базової і повної загальної середньої освіти [Електронний ресурс] / Постанова від 23 листопада 2011 р. № 1392 Про затвердження Державного стандарту базової і повної загальної середньої освіти. - Режим доступу : http : // www.mon.gov.ua / ua / often-requested / state-standards - Назва з екрану.

4. Савченко О. Я. Наступність і перспектива в роботі двох перших ланок освіти / О. Я. Савченко // Дошкільне виховання. - 2000. - № 11. - С. 4-5.

5. Хитрук В. Наступність у формуванні змісту підготовки майбутніх учителів природничо-наукових дисциплін / В. Хитрук // Наукові записки. - Випуск 5. - Серія : Проблеми методики фізико-математичної і технологічної освіти. Частина 1. - Кіровоград : РВВ КДПУ ім. В. Винниченка, 2014 - 238 с.

\section{REFERENCES (TRANSLATED \& TRANSLITERATED)}

1. Tanska V. V. Metodyka navchannia pryrodoznavstva u pochatkovii shkoli [Methods for Teaching Natural Science in Primary School] : [navch.-metod posibnyk] / V. V. Tanska. - Zhytomyr : Vyd-vo ZhDU im. I. Franka, 2014. $236 \mathrm{~s}$.

2. Romanenko L. Nastupnist' pryrodnychoi osvity v doshkilli - pochatkovii shkoli - osnovnii shkoli [Continuity of Natural Science Education in Primary, Middle and High School] / L. Romanenko // Osoblyvosti osvity ditei shestyrichnoho viku : problemy, poshuky, dosvid, znakhidky [Characteristics of Education of Six-Year-Old Children: Problems, Research, Experience, Findings]. - Materialy Vseukrainskoi naukovo-praktychnoi konferentsii (Kyiv, 19-20 lystopada 2003 roku). - K. : KMPU imeni B. D. Hrinchenka, 2004. - 138 s.

3. Derzhavnyi standart bazovoi i povnoi zahal'noi serednoi osvity [State Standard of Basic and Complete General Secondary Education] [Elektronnyi resurs] / Postanova vid 23 lystopada 2011 r. № 1392 Pro zatverdzhennia Derzhavnoho standartu bazovoi i povnoi zahalnoi serednoi osvity [The Decree № 1392 of 23 November, 2011 On the Approval of State Standard of Basic and Complete General Secondary Education]. - Rezhym dostupu : http : // www.mon.gov.ua / ua / often-requested / state-standards - Nazva z ekranu.

4. Savchenko O. Ya. Nastupnist' i perspektyva v roboti dvokh pershykh lanok osvity [Continuity and Perspectives of First Two Educational Stages]] / O. Ya. Savchenko // Doshkil'ne vykhovannia [Preschool Education]. - 2000. № $11 .-$ S. 4-5.

5. Khytruk V. Nastupnist' u formuvanni zmistu pidhotovky maibutnikh uchyteliv pryrodnycho-naukovykh dystsyplin [Continuity of the Content Formation of Prospective Natural Science Teachers' Preparation]/ V. Khytruk // Naukovi zapysky [Academic Writings]. - Vypusk 5. - Seriia : Problemy metodyky fizyko-matematychnoi i tekhnolohichnoi osvity. -Chastyna 1. - Kirovohrad : RVV KDPU im. V. Vynnychenka, 2014-238 s.

\section{Танская В. В. Теоретические основы реализации принципа преемственности в преподавании естественных дисциплин общцеоразовательной иколь.}

В статье раскрывается важность обеспечения принципа преемственности естественнонаучного образования между дошкольной, начальной, основной школой, который в дальнейшем углубляется на основе профильного обучения в старшей школе. Выяснено, что обеспечение преемственности естественнонаучного образования осуществляется целенаправленно и многоаспектно путем формирования естественнонаучной компетентности и предметных компетентностей как обязательных составляющих общей культуры учеников.

Ключевые слова: перспективность, принции преемственности, предметная компетентность, естественнонаучная компетентность.

\section{Tanska V. V. Theoretical Bases for the Implementation of the Principle of Continuity in the Teaching of Natural Sciences of the Secondary School.}

The article reveals the importance of ensuring the principle of continuity of natural education between preschool, primary, basic school, which is further deepened on the basis of profile education in high school. The complexity, the theoretical and practical significance of the problem of implementing the principle of continuity in the teaching of natural sciences disciplines of the secondary school determined the breadth of its research in psycho-pedagogical and special literature. It was found out that ensuring the continuity of natural education is carried out purposefully and multi-faceted, by forming the scientific and scientific competency and subject 
competences as obligatory components of the general culture of students. Natural scientific competence involves the readiness of students to explain and appropriate attitude to nature, awareness of the image of nature as a contemporary natural sciences picture of the world. Formation of subject competences promotes the mastering of fundamental ideas, principles that promote the development of skills in interaction with the environment. Summarizing the above, we note that continuity in the educational process is of great importance. It enables gradually to increase the volume of concepts and methods of action, as well as to create a complete picture of the world in the students, affects the student's motivation, allows the teacher to use productive means, teaching methods, and research and search situations in the educational process. Thus, to intensify cognitive activity of students, gradually increase the load on them. The presented material allows us to conclude that ensuring the continuity of natural education students of secondary schools should be purposefully and multi-faceted.

Key words: perspective, principle of continuity, subject competence, natural sciences competence. 